Cochrane Database of Systematic Reviews

\title{
Intranasal steroids for acute sinusitis (Review)
}

Zalmanovici Trestioreanu A, Yaphe J

Zalmanovici Trestioreanu A, Yaphe J.

Intranasal steroids for acute sinusitis.

Cochrane Database of Systematic Reviews 2013, Issue 12. Art. No.: CD005149.

DOI: 10.1002/14651858.CD005149.pub4.

www.cochranelibrary.com 
TABLE OF CONTENTS

HEADER 1

ABSTRACT

PLAIN LANGUAGE SUMMARY

BACKGROUND

OBJECTIVES

METHODS

RESULTS

Figure 1.

Figure 2.

DISCUSSION

AUTHORS' CONCLUSIONS

ACKNOWLEDGEMENTS

REFERENCES

CHARACTERISTICS OF STUDIES

DATA AND ANALYSES

Analysis 1.1. Comparison 1 Intranasal corticosteroids versus placebo, Outcome 1 Proportion of participants with resolution of symptoms or improved (MFNS $400 \mu \mathrm{g}$ daily).

Analysis 1.2. Comparison 1 Intranasal corticosteroids versus placebo, Outcome 2 Proportion of participants with resolution of symptoms or improved (MFNS $200 \mu \mathrm{g}$ daily).

Analysis 1.3. Comparison 1 Intranasal corticosteroids versus placebo, Outcome 3 Proportion of participants with resolution of symptoms or improved (combined MFNS 200, 400 and $800 \mu \mathrm{g}$ daily).

Analysis 1.4. Comparison 1 Intranasal corticosteroids versus placebo, Outcome 4 Number of participants that dropped out from the study (MFNS $400 \mu \mathrm{g}$ daily).

Analysis 1.5. Comparison 1 Intranasal corticosteroids versus placebo, Outcome 5 Number of participants that dropped out from the study (MFNS $200 \mu \mathrm{g}$ daily).

Analysis 1.6. Comparison 1 Intranasal corticosteroids versus placebo, Outcome 6 Number of participants that dropped out from the study (combined MFNS 200, 400 and $800 \mu \mathrm{g}$ daily).

Analysis 1.7. Comparison 1 Intranasal corticosteroids versus placebo, Outcome 7 Relapse (combined 200 and $400 \mu g$ daily). ... ADDITIONAL TABLES

APPENDICES

WHAT'S NEW

HISTORY

CONTRIBUTIONS OF AUTHORS

DECLARATIONS OF INTEREST

NOTES

INDEX TERMS 
[Intervention Review]

\section{Intranasal steroids for acute sinusitis}

Anca Zalmanovici Trestioreanuํㅗ , John Yaphe 2

${ }^{1}$ Clalit Health Services, Tel Aviv District, Tel Aviv, Israel. ${ }^{2}$ School of Health Science, University of Minho, Braga, Portugal

Contact address: Anca Zalmanovici Trestioreanu, Clalit Health Services, Tel Aviv District, Amsterdam 9, Tel Aviv, 6936181, Israel. anca_z@hotmail.com,anka2@012.net.il.

Editorial group: Cochrane Acute Respiratory Infections Group.

Publication status and date: Edited (no change to conclusions), published in Issue 8, 2019.

Citation: Zalmanovici Trestioreanu A, Yaphe J. Intranasal steroids for acute sinusitis. Cochrane Database of Systematic Reviews 2013, Issue 12. Art. No.: CD005149. DOI: 10.1002/14651858.CD005149.pub4.

Copyright @ 2019 The Cochrane Collaboration. Published by John Wiley \& Sons, Ltd.

\section{A B S T R A C T}

\section{Background}

Acute sinusitis is a common reason for primary care visits. It causes significant symptoms and often results in time off work and school.

\section{Objectives}

We examined whether intranasal corticosteroids (INCS) are effective in relieving symptoms of acute sinusitis in adults and children.

\section{Search methods}

We searched CENTRAL 2013, Issue 4, MEDLINE (January 1966 to May week 2, 2013), EMBASE (1990 to May 2013) and bibliographies of included studies.

\section{Selection criteria}

Randomised controlled trials (RCTs) comparing INCS treatment to placebo or no intervention in adults and children with acute sinusitis. Acute sinusitis was defined by clinical diagnosis and confirmed by radiological evidence or by nasal endoscopy. The primary outcome was the proportion of participants with either resolution or improvement of symptoms. Secondary outcomes were any adverse events that required discontinuation of treatment, drop-outs before the end of the study, rates of relapse, complications and return to school or work.

\section{Data collection and analysis}

Two review authors independently extracted data, assessed trial quality and resolved discrepancies by consensus.

\section{Main results}

No new trials were found for inclusion in this update. Four studies involving 1943 participants with acute sinusitis met our inclusion criteria. The trials were well-designed and double-blind and studied INCS versus placebo or no intervention for 15 or 21 days. The rates of loss to follow-up were $7 \%, 11 \%, 41 \%$ and $10 \%$. When we combined the results from the three trials included in the meta-analysis, participants receiving INCS were more likely to experience resolution or improvement in symptoms than those receiving placebo $(73 \%$ versus $66.4 \%$; risk ratio (RR) 1.11; $95 \%$ confidence interval (CI) 1.04 to 1.18). Higher doses of INCS had a stronger effect on improvement of symptoms or complete relief: for mometasone furoate $400 \mu \mathrm{g}$ versus $200 \mu \mathrm{g}$ (RR 1.10; 95\% Cl 1.02 to 1.18 versus RR $1.04 ; 95 \% \mathrm{Cl} 0.98$ to 1.11 ). No significant adverse events were reported and there was no significant difference in the drop-out and recurrence rates for the two treatment groups and for groups receiving higher doses of INCS. 


\section{Authors' conclusions}

Current evidence is limited for acute sinusitis confirmed by radiology or nasal endoscopy but supports the use of INCS as a monotherapy or as an adjuvant therapy to antibiotics. Clinicians should weigh the modest but clinically important benefits against possible minor adverse events when prescribing therapy.

\section{PLAIN LANGUAGE SUMMARY}

\section{Steroids for acute sinusitis in adults and children}

Acute sinusitis is a common reason for primary care visits; it is one of the 10 most common diagnoses in outpatient clinics, presenting with various symptoms and signs that include purulent nasal discharge and congestion and cough lasting beyond the typical seven to 10 days of a viral upper respiratory infection. There have been suggestions, based on studies of allergic rhinitis and chronic sinusitis, that intranasal corticosteroids (INCS) may relieve symptoms and hasten recovery in acute sinusitis due to their anti-inflammatory properties.

A critical systematic review of the literature found four well-conducted, randomised, placebo-controlled intervention studies, involving 1943 participants treated for 15 or 21 days. The results suggest that there may be a modest effect with INCS in the resolution or improvement of symptoms. Only minor adverse events such as epistaxis, headache and nasal itching were reported. Given the small number of studies included in this review, it is recommended that further randomised controlled trials be conducted. The evidence is up to date as of May 2013. 


\section{B A C K G R O U N D}

\section{Description of the condition}

Acute sinusitis is a common reason for primary care visits. It causes significant symptoms and often results in time off work and school. It is one of the 10 most common diagnoses in ambulatory practice and is the fifth most common diagnosis for which an antibiotic is prescribed. Primary care physicians tend to think of sinusitis as an acute bacterial infection and consequently prescribe antibiotics in $85 \%$ to $98 \%$ of cases. However, sinusitis is frequently caused by a viral infection. According to epidemiological estimates, only $0.2 \%$ to $2 \%$ of viral upper respiratory tract infections in adults are complicated by bacterial rhinosinusitis. It will often resolve in most patients without antibiotic treatment, even if it is bacterial in origin. Since no simple and accurate practice-based test exists for acute bacterial sinusitis, clinicians rely on clinical findings to make the diagnosis. Signs and symptoms of acute bacterial sinusitis and those of prolonged viral upper respiratory tract infection are very similar, resulting in frequent misclassification of viral cases (Snow 2001).

The common cold is associated with frequent and variable anatomical involvement of the upper airways, including occlusion and abnormalities in the sinus cavities (Gwaltney 1994). Rhinorrhoea, sinus tenderness, purulent secretions and a history of sinusitis were significant predictors for the diagnosis of sinusitis in a retrospective analysis (Little 2000). Acute sinusitis is defined as an inflammation of the sinuses with the symptom complex lasting less than eight weeks in adults and less than 12 weeks in children (Kaliner 1997).

Clinical diagnosis is made through the appearance of a characteristic constellation of symptoms and signs, including purulent nasal discharge and congestion and cough lasting beyond the typical seven to 10 days for a viral upper respiratory infection. Fever and facial pain may also occur. Diagnosis is often confirmed by sinus imaging; in this area, the use of computerised tomography (CT) scanning is gaining favour (Gwaltney 1995).

Inflammation of nasal mucosa plays an essential role in the development of sinusitis (Tutkun 1996). Sinusitis is invariably accompanied by inflammation of the contiguous nasal mucosa, therefore rhinosinusitis has become the preferred term (Snow 2001). The precipitating factor in acute sinusitis appears to be blockage of the sinus ostium. The obstruction, as well as mucus retention and infection, produce the characteristic signs and symptoms of rhinosinusitis. Although many conditions may lead to ostial closure, viral upper respiratory infections and allergic inflammation are by far the most frequent and important (Shapiro 1992).

\section{Description of the intervention}

Treatment of sinusitis is aimed at eliminating causative factors and controlling the inflammatory and infectious components (Becker 2003). It has been theorised that by decreasing the inflammatory response and reducing the mucosal swelling, a topical intranasal steroid would promote drainage and increase aeration of the sinuses, thus hastening the elimination of infectious organisms and decreasing the frequency and severity of recurrences (Mygind 1976). There is evidence that asthma, otitis media with effusion and acute sinusitis may all benefit from such therapy as well
(Scadding 2000). A recent Cochrane review found that systemic corticosteroids as adjunctive to antibiotic treatment were effective for the short-term relief of symptoms in acute sinusitis; the authors mention that the data for this review are limited and there is a significant risk of bias (Venekamp 2011).

\section{How the intervention might work}

In addition to treating seasonal and perennial rhinitis (possible predisposing factors to the development of acute rhinosinusitis), intranasal corticosteroids (INCS) might be beneficial in reducing inflammation in the treatment of sinusitis and may help decrease secondary rhinovirus infections (Gawchik 2000). The mode of action of INCS is complex. It is not known whether INCS penetrate the nasal mucosa or act on target cells. However, their low systemic activity supports the concept of local action on nasal mucosa. This local effect can influence a variety of inflammatory cells and their mediators such as epithelial cells, lymphocytes, basophiles, mast cells and Langerhans cells. Corticosteroid-induced inhibition of the immunoglobulin $\mathrm{E}$ dependent release of histamine is a possible but unproven mode of action (Mygind 2001).

\section{Why it is important to do this review}

The management of rhinosinusitis depends on a number of variables related to the duration and severity of symptoms in the individual patient. Since there are a variety of conservative and pharmacological interventions available, the physician can find it difficult to develop a cohesive and logical approach to treatment (Benninger 1997). A small benefit for clinical outcomes was observed in patients treated with antibiotics for uncomplicated acute sinusitis; $80 \%$ of participants treated without antibiotics improved within two weeks (Ahovuo-Saloranta 2011). No clear evidence of efficacy of decongestants, antihistamines and nasal irrigations for acute sinusitis in children was found in a recent Cochrane Review (Shaikh 2012). Recent practice guidelines for the diagnosis and management of rhinosinusitis suggest considering the use of INCS as adjunctive therapy (Slavin 2005; Spector 1998). Although the guidelines reflect the belief of many clinicians that INCS are a valuable component of rhinosinusitis management, limited clinical data are available on their use in this disease. A recent experimental prospective study on rabbits with surgically introduced sinusitis demonstrated no clear advantage of steroids in the treatment of sinus infections using this model (Cable 2000). The use of adjunctive medications for acute sinusitis such as antihistamines, decongestants and nasal steroids also remains controversial (Shrum 2001). Several recent studies tested the effectiveness of inhaled steroids for relieving symptoms in acute sinusitis in humans, concluding that this treatment is effective. A systematic review that addresses the effectiveness of this therapy will provide useful information to all primary care practitioners and could assist in formulating the best treatment plan for the individual patient.

\section{OBJECTIVES}

We examined whether intranasal corticosteroids (INCS) are effective in relieving symptoms of acute sinusitis in adults and children. 


\section{METHODS}

\section{Criteria for considering studies for this review \\ Types of studies}

Randomised controlled trials (RCTs) comparing topical intranasal steroids with placebo or no intervention.

\section{Types of participants}

1. Children and adults, irrespective of age, with acute sinusitis.

2. Acute sinusitis is defined by clinical diagnosis and nasal endoscopy or radiological evidence or nasal endoscopy.

3. We included trials including a mixed population of acute and non-acute sinusitis if outcomes were reported separately for these subgroups.

\section{Types of interventions}

Studies which used intranasal corticosteroids (INCS) - any preparation, dose or route of administration (for example, inhaled or drops) versus placebo or no intervention in the control group. We included trials reporting combined interventions only if the control arm received the same co-treatments as the intervention arm, except for topical steroids.

\section{Types of outcome measures}

\section{Primary outcomes}

1. Proportion of participants with resolution or improvement of symptoms.

\section{Secondary outcomes}

1. Any adverse event that necessitated discontinuation of treatment.

2. Proportion of participants that developed complications.

3. Drop-outs before the end of the study.

4. Rates of relapse in symptoms.

5. Proportion of participants that returned to school or work within a specific time frame.

\section{Search methods for identification of studies}

\section{Electronic searches}

For this update we searched the Cochrane Central Register of Controlled Trials (CENTRAL) 2013, Issue 4, part of The Cochrane Library, www.thecochranelibrary.com (accessed 22 May 2013), which contains the Cochrane Acute Respiratory Infections Group's Specialised Register; MEDLINE (April 2011 to May week 2, 2013) and EMBASE (April 2011 to May 2013). See Appendix 1 for details of previous searches.

We searched MEDLINE and CENTRAL using the following search strategy. We combined the MEDLINE search with the Cochrane Highly Sensitive Search Strategy for identifying randomised trials in MEDLINE: sensitivity- and precision-maximising version (2008 revision); Ovid format (Lefebvre 2011). We adapted the strategy to search EMBASE (Appendix 2).

\section{MEDLINE (OVID)}

1 exp Sinusitis/

2 sinusit*.tw.
3 (rhinosinusit* or nasosinusit ${ }^{\star}$ ).tw.

4 or $/ 1-3$

5 exp Steroids/

6 steroid ${ }^{\star}$. tw.

7 exp Adrenal Cortex Hormones/

8 adrenal cortex hormone ${ }^{\star}$.tw.

9 exp Anti-Inflammatory Agents/

10 anti-inflammat*.tw.

11 corticosteroid ${ }^{*}$. tw.

12 or $/ 5-11$

13 exp Administration, Intranasal/

14 exp Administration, Topical/

15 (nasal $^{\star}$ or intranasal ${ }^{\star}$ or topical $\left.{ }^{\star}\right)$.tw.

16 or $/ 13-15$

1712 and 16

184 and 17

\section{Searching other resources}

We inspected the reference lists in all identified studies for further relevant studies. We also scrutinised the existing review literature (for example, Mucha 2003). We contacted trial authors for information about possible unpublished studies. There were no language or publication restrictions. We also searched the WHO ICTRP and ClinicalTrials.gov trials registries (14 May 2013) for completed and ongoing trials.

\section{Data collection and analysis}

\section{Selection of studies}

The two review authors independently reviewed the abstracts of potential studies to be included in the review. We obtained the full article and independently inspected it for relevance.

\section{Data extraction and management}

The two review authors independently extracted data from included trials. We documented disagreements and resolved them by discussion. We contacted the trial authors for clarification when necessary. We also documented justification for excluding studies from the review in the Characteristics of excluded studies table. We reported on the following domains.

1. Characteristics of trials: publication status, year, country of study, setting, design, inclusion and exclusion criteria, recruitment, methods, analysis, results.

2. Characteristics of participants: study population, number of participants in each group, age, gender, nationality, diagnostic criteria.

3. Characteristics of interventions: preparation used, dose, length of treatment and follow-up, compliance, co-interventions.

4. Outcomes: resolution of symptoms, improvement of symptoms, relapse, complications, return to school/work, adverse events related to the intervention, drop-outs before the end of the study and reasons for dropping out.

\section{Assessment of risk of bias in included studies}

The two review authors independently assessed the methodological quality of each study in the 'Risk of bias' tables, as outlined in the Cochrane Handbook for Systematic Reviews of Interventions (Higgins 2011):

1. random sequence generation; 
2. allocation concealment;

3. blinding of participants and personnel;

4. blinding of outcome assessment;

5. incomplete out come data;

6. selective reporting; and

7. other bias.

We included trials if they met the following criteria: randomisation method described that would not allow the investigator/ participant to know or influence intervention group before the eligible participant entered in the study (low risk of bias) and randomisation stated but no information on method used is available (moderate risk of bias). There were no disagreements and we observed no selective reporting or other potential bias. We obtained additional information from the trial authors when the publications presented insufficient detail.

\section{Measures of treatment effect}

We analysed dichotomous data by calculating the risk ratio (RR) and risk difference (RD) for each trial with the uncertainty in each result being expressed as 95\% confidence interval $(\mathrm{Cl})$. We expressed the results using the approach recommended in the Cochrane Handbook for Systematic Reviews of Interventions (Higgins 2011). We performed all analyses on the basis of intention-to-treat (ITT). We divided study data as far as possible from published and unpublished information into subgroups for children less than 18 years, adults and co-interventions. We planned subgroup analyses to assess the impact of these possible sources of heterogeneity. We used the fixed-effect model for combining studies in the absence of heterogeneity.

\section{Unit of analysis issues}

We included RCTs with standard designs and parallel groups in the review.

\section{Dealing with missing data}

We tried to contact study authors for missing data.

\section{Assessment of heterogeneity}

We assessed heterogeneity by inspection of the graphical presentations and $1^{2}$ statistic for heterogeneity.

\section{Assessment of reporting biases}

We did not have sufficient studies for performing funnel plot analysis to assess possible publication bias. We did not observe other reporting bias.

\section{Data synthesis}

We did not find any evidence of heterogeneity between studies as assessed by inspection of the graphical presentations; therefore we used the fixed-effect model for combining the studies.

\section{Subgroup analysis and investigation of heterogeneity}

We did not perform the planned subgroup analyses as the included studies did not report data for these subgroups.

\section{Sensitivity analysis}

We planned no sensitivity analyses in the absence of heterogeneity.

\section{RES U L T S}

\section{Description of studies}

\section{Results of the search}

We did not identify any trials to include or exclude in this 2013 update from the 82 new references identified. In the previous review (Zalmanovici Trestioreanu 2011) 495 references were identified and the abstracts were inspected by the two review authors.

\section{Included studies}

Four studies with 1943 participants assigned to intranasal corticosteroids (INCS) or placebo met the inclusion criteria for this review. Three studies were multicentre trials; one was conducted at 22 sites -12 primary care and 10 otolaryngology clinics (Dolor 2001), one study involved outpatients from 61 treatment centres in the USA (Nayak 2002), one study was conducted at 71 medical centres in 14 countries (Meltzer 2005) and one study involved participants from the Marmara University Hospital Pediatric Outpatient Clinic (Barlan 1997).

One trial had three treatment arms; two arms for different doses of INCS and one arm for placebo (Nayak 2002). One trial had four treatment arms; two arms for different doses of INCS, one arm for antibiotic and one arm for placebo (Meltzer 2005). We performed meta-analyses for treatment arms using different doses of INCS combined and separately.

\section{Participants}

Participants included in the trials were children and adults with a documented episode of acute sinusitis, confirmed by radiology or nasal endoscopy. The entry criteria in the trials were similar.

\section{Intervention}

All the studies used a placebo in the control group. Participants in the treatment groups in three studies received INCS for 21 days as fluticasone propionate two puffs daily in each nostril, giving a total dose of $200 \mu \mathrm{g}$ (Dolor 2001), MFNS (mometasone furoate) twice daily giving a total dose of $400 \mu \mathrm{g}$ or $800 \mu \mathrm{g}$ (Nayak 2002) and budesonide $50 \mu \mathrm{g}$ twice daily to each nostril as a nasal spray (Barlan 1997) as adjuvant therapy to antibiotics. One study used MFNS 200 $\mu \mathrm{g}$ and $400 \mu \mathrm{g}$ total daily dose in the treatment arms for 15 days as monotherapy (Meltzer 2005). Other concomitant therapies were similar in all groups, in every study.

\section{Outcomes}

The included studies reported the proportion of participants with clinical success; the length of time until clinical success; difference over time in sinusitis symptoms; quality of life scores; relapse (Dolor 2001); improvement in total and individual symptoms scores; onset of relief and evaluation of changes in computerised tomography (CT) sinus scans (Nayak 2002); difference in weekly symptom scores as difference between groups or change from baseline (Barlan 1997); global response to treatment; time to onset of action; mean major symptom scores; mean total symptom scores; individual symptom scores; treatment failure and disease recurrence (Meltzer 2005). Information on adverse events that occurred during the trials is presented in Table 1. Drop-outs before the end of the study and the reasons for leaving were described in all the studies. One study did not report separate data for the groups for this 
outcome and the number of participants initially randomised in each group had a high drop-out rate. It reported results as medians of scores using non-parametric tests because a wide range of scores were without normal distribution; it was not included in the metaanalyses (Barlan 1997).

\section{Excluded studies}

We excluded 491 studies for one or more of the following reasons: not acute sinusitis; not randomised; observational studies; intervention of interest not used; no relevant outcomes reported; repeated reports of the same study; and review articles. Thirteen reports were considered potentially eligible for inclusion but after inspection of the full papers, we excluded nine (Bachert 2007; Gehanno 2000; Jurkiewicz 2004; Meltzer 1993; Meltzer
2000; Quarnberg 1992; Tutkun 1996; Williamson 2007; Yilmaz 2000) (see Characteristics of excluded studies table). In the first publication of this review (Zalmanovici 2007) two studies were awaiting further assessment for missing data (Meltzer 2000; Tutkun 1996). We excluded these studies in the first update (Zalmanovici 2009) as data were not made available from the trial authors, whom we contacted. The reasons for exclusion are added to the Characteristics of excluded studies table. In addition, for one study (Jurkiewicz 2004), no abstract or full paper was available.

\section{Risk of bias in included studies}

The studies were well-designed, randomised, double-blind, placebo-controlled trials. The overall risk of bias is presented graphically in Figure 1 and summarised in Figure 2.

Figure 1. 'Risk of bias' graph: review authors' judgements about each risk of bias item presented as percentages across all included studies.




Figure 2. 'Risk of bias' summary: review authors' judgements about each risk of bias item for each included study.

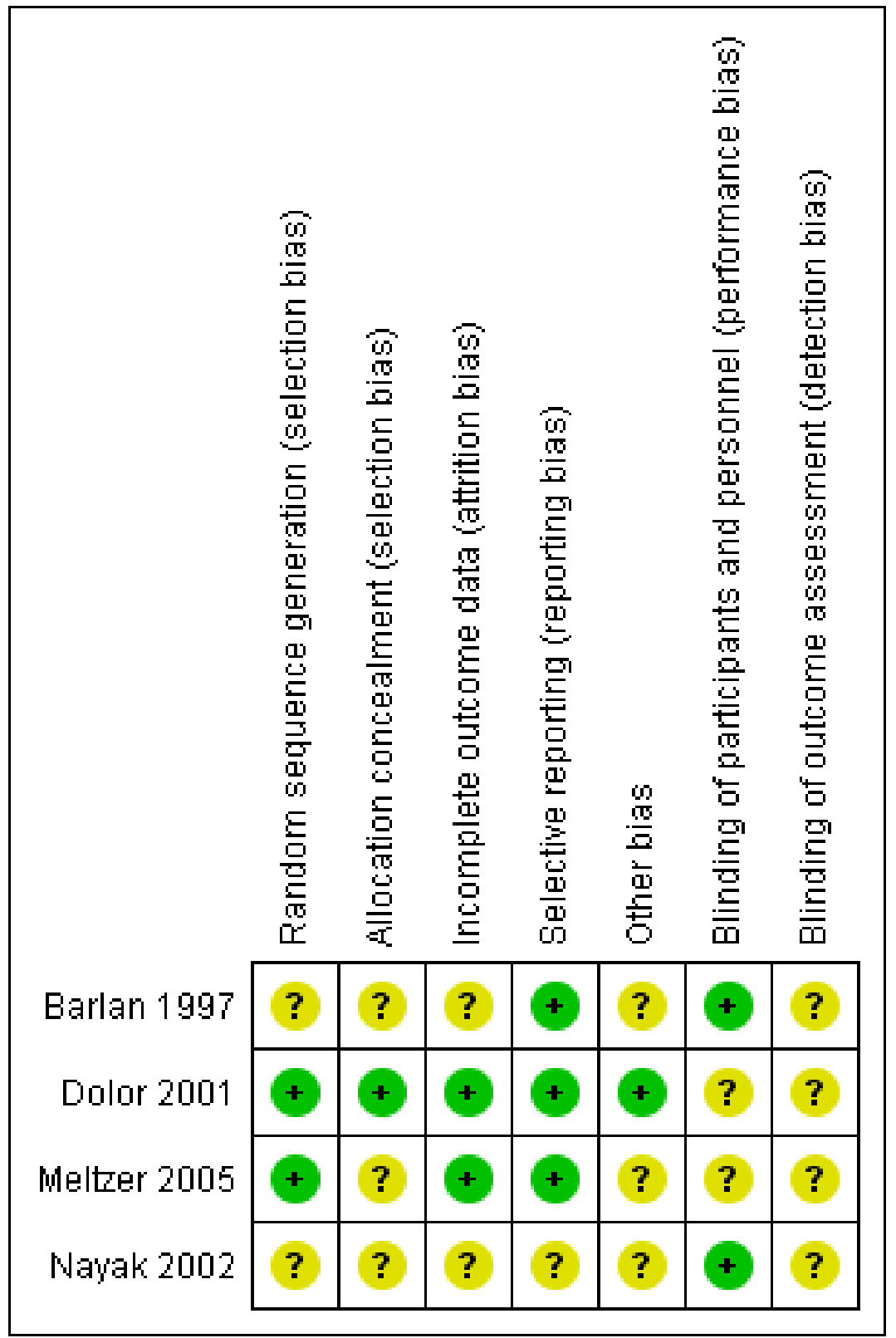

\section{Allocation}

All four studies were RCTs. However, only two contained an adequate report of the generation of allocation sequence (Dolor 2001; Meltzer 2005) and one study reported concealment of allocation (Dolor 2001). The assessment for trial inclusion was based on allocation concealment.

\section{Blinding}

The trials were double-blinded and the method of blinding was adequate. One study did not describe the method of blinding (Barlan 1997).

\section{Incomplete outcome data}

Drop-outs before the end of the study and the reasons for leaving were described in the studies. The total loss to follow-up was
7\% (Dolor 2001), 11\% (Nayak 2002), 10\% (Meltzer 2005) and 41\% (Barlan 1997), respectively.

\section{Selective reporting}

The studies reported what was pre-stated in their protocol.

\section{Other potential sources of bias}

We identified no other sources of bias.

\section{Effects of interventions}

Four studies that included 1943 participants met our inclusion criteria (Barlan 1997; Dolor 2001; Meltzer 2005; Nayak 2002). Two studies had more than two arms, two treatment arms for different doses of intranasal corticosteroids (INCS), and we performed separate and combined dose meta-analyses (Meltzer 2005; Nayak 
2002). One study was included in the review but not in the metaanalysis as it was not possible to extract data, non-parametric tests were used and it had a high drop-out rate (Barlan 1997).

\section{Primary outcome}

\section{Proportion of participants with resolution or improvement of symptoms}

Information on our primary outcome was found in three trials, assessed at 15 days in one study (Meltzer 2005) and at 21 days in two other studies (Dolor 2001; Nayak 2002). When combined using intention-to-treat (ITT) analysis, $73 \%$ of INCS-treated participants and $66.4 \%$ of controls had resolution or marked improvement of symptoms (for every 100 patients treated with INCS seven additional patients had complete or marked symptom relief). Individuals treated with INCS (combined results for the $200 \mu \mathrm{g}$, $400 \mu \mathrm{g}$ and $800 \mu \mathrm{g}$ doses) were more likely to have complete relief or improvement than the placebo group (risk ratio (RR) 1.11; 95\% confidence interval $(\mathrm{Cl}) 1.04$ to 1.18 ) (Analysis 1.3); (risk difference (RD) $0.07 ; 95 \% \mathrm{Cl} 0.03$ to 0.11 ) and this result was statistically significant. When we performed separate metaanalyses for different doses of INCS, a stronger and statistically significant effect was obtained when patients were treated with $400 \mu \mathrm{g}$ than $200 \mu \mathrm{g}$ mometasone furoate (MFNS) total daily dose (RR $1.10 ; 95 \% \mathrm{Cl} 1.02$ to 1.18 versus RR $1.04 ; 95 \% \mathrm{Cl} 0.98$ to 1.11 ) (Analysis 1.1; Analysis 1.2); (RD $0.06 ; 95 \% \mathrm{Cl} 0.02$ to 0.11 versus RD $0.04 ; \mathrm{Cl} 95 \%-0.02$ to 0.09 ). The attributable risk percentage (AR\%) calculated for the results that were statistically significant means that $8 \%$ (one in 12) of all patients who, having received the $400 \mu \mathrm{g}$ dose of INCS, had resolution or improvement in symptoms could attribute that relief to the treatment. When calculated from results combined across all doses, the number is $9 \%$ (one in 11 ). One study that used in one of the treatment arms an $800 \mu \mathrm{g}$ MFNS daily dose found a statistically significant effect for this dose (RR 1.21;95\% Cl 1.05 to 1.39 ) (Nayak 2002).

\section{Secondary outcomes}

\section{Any adverse event that necessitated discontinuation of treatment}

This outcome was reported in two studies (Meltzer 2005; Nayak 2002). No separate data for each treatment arm were available in one study (Nayak 2002) and the participants were equally distributed among the three arms. One study reported a drop-out rate from treatment of $1 \%, 3 \%, 2 \%$ and $2 \%$ because of adverse events in the INCS $200 \mu \mathrm{g}, 400 \mu \mathrm{g}$, antibiotic and placebo arms (Meltzer 2005) (Table 1).

\section{Proportion of participants that developed complications}

No studies reported this outcome.

\section{Drop-outs before the end of the study}

This outcome is reported in three studies (Dolor 2001; Meltzer 2005; Nayak 2002). No statistically significant difference could be found for participants that were lost to follow-up in the two groups (RR $0.85 ; 95 \% \mathrm{Cl} 0.64$ to 1.12 ) (Analysis 1.6). Using a higher dose of INCS did not change the results (RR $0.86 ; 95 \% \mathrm{Cl} 0.61$ to 1.20 ) (Analysis 1.4) for MFNS $400 \mu \mathrm{g}$ versus MFNS $200 \mu \mathrm{g}$ (RR $0.75 ; 95 \% \mathrm{Cl} 0.46$ to 1.21) (Analysis 1.5).

\section{Rates of relapse in symptoms}

Two studies reported data for this outcome (Dolor 2001; Meltzer 2005). No statistically significant differences could be found between groups; $6.3 \%$ and $10 \%$ had relapse in the INCS and placebo groups (RR $0.71 ; 95 \% \mathrm{Cl} 0.44$ to 1.15 ) (Analysis 1.7). The median time to first recurrence was three days earlier in the placebo group (22 versus 25 days) in one study (Dolor 2001). One study did not find significant differences between groups for different doses of INCS (Meltzer 2005).

\section{Proportion of participants that returned to school or work within a specific time frame}

No studies reported this outcome. One study (Dolor 2001) reported a higher subjective level of work performance that was significantly different on day 21 (P value $=0.009)$ in the INCS treatment group versus placebo. The difference between groups with respect to the total number of hours missed from work was not significant ( $P$ value $=0.40$ ).

\section{DISCUSSION}

Acute sinusitis is typically first seen as an upper respiratory tract infection that has persisted beyond five to seven days. The diagnosis of sinusitis is based on a combination of clinical history with physical examination, nasal cytology or imaging studies (or both). Factors that may predispose to sinusitis include allergic or occupational rhinitis, vasomotor rhinitis, nasal polyps, rhinitis medicamentosa and immunodeficiency (Spector 1998). Although acute sinusitis is an infectious disease in which several bacterial species play a major aetiological role, there is an important interaction between respiratory viruses (for example, common cold viruses) and bacteria in the pathogenesis of acute communityacquired sinusitis (Winther 1990). Upper respiratory tract infections and allergic inflammation are recognised as the important risk factors for acute sinusitis, with upper respiratory tract infection being the most common (Wald 1988).

\section{Summary of main results}

Four studies met the inclusion criteria in our review. They were well-conducted and produced results that suggest a clinically relevant, earlier resolution of symptoms in participants treated with intranasal corticosteroids (INCS), without the risk of severe adverse events, even when higher doses in the therapeutic range were used. All four of the trials reached statistical significance for this outcome. One in 12 of all patients who having received the $400 \mu \mathrm{g}$ dose had resolution or improvement in symptoms could attribute that relief to the treatment. Across all doses, the number is one in 11. No statistically significant difference in the relapse rate between groups was found. One study (Barlan 1997) found that INCS may be a useful ancillary treatment to antibiotics in childhood sinusitis and effective in reducing the cough and nasal discharge earlier in the course of acute sinusitis. Clinical signs and symptoms decreased significantly in both groups in comparison to baseline $(P$ $<0.01$ ) and in the intervention group when compared to placebo in the scores for cough and nasal discharge at the end of the second week $(P<0.05)$. This study was not included in the meta-analyses as it had a high drop-out rate (41\%), drop-outs were not described separately for both groups, outcomes were reported as weekly scores using non-parametric tests and it was not possible to extract data for our outcomes. One of the included studies (Nayak 2002) 
found a significant improvement in the total symptom score and in individual symptom scores during the treatment period.

The mean change in the score from computerised tomography (CT) scans of the sinuses from baseline to day 21 was not statistically significant between the treatment and control groups. One other included study (Dolor 2001) found the median number of days to clinical success in those treated with INCS was six days compared to nine and a half days in those treated with a placebo. The subjective level of work performance at 21 days was significantly better in the treatment group. Improvement in sinusitis symptoms scores, sinusitis-related quality of life and the total number of hours of work missed were not significantly different in the two groups. Mometasone furoate (MFNS) $400 \mu \mathrm{g}$ daily demonstrated significant superiority over MFNS $200 \mu \mathrm{g}$ daily in nasal congestion/stuffiness score $(P=0.013)$ and global response to treatment $(P=0.002)$ was more consistently superior across the endpoints and over amoxicillin in one study (Meltzer 2005), suggesting that higher doses are needed. Also, this study found significant improvement in the major symptom score $(P<0.001)$, total symptom score ( $P$ $<0.001)$, global response to treatment $(P=0.001)$ and individual symptom scores (rhinorrhoea, nasal congestion/stuffiness, sinus headache, facial pain) for MFNS $400 \mu \mathrm{g}$ over placebo.

The results of these studies and reviews support the current clinical rationale of adding an INCS to antibiotic therapy for acute episodes of rhinosinusitis and suggest that higher doses are needed; effectiveness as monotherapy remains to be demonstrated by further studies. The included studies enrolled adults and children and the samples were representative of participants that physicians would recognise as common in their practice. Clinical improvement was assessed by patient-derived (subjective) symptom reports and this outcome met one of our study goals: evaluating alleviation of symptoms together with possible adverse events.

\section{Overall completeness and applicability of evidence}

It is important that the mucous membranes and ciliary function are restored to normal as soon as possible, to avoid recurrence or development of chronic sinusitis (Quarnberg 1992). Two surveys of primary care and specialty physicians suggested considerable variability in approaches to treatment (Piccirillo 2001; Williams 1993). Recommendations for appropriate treatment for acute sinusitis range from symptomatic treatment alone (Snow 2001) to a prolonged course of antibiotic therapy (Winther 1990). A variety of ancillary treatments aimed at improving nasal and sinus ostial patency (antihistamines, decongestants, INCS and nasal irrigation) might be helpful in the treatment of sinusitis but there are few controlled studies to support or deny their effectiveness (Zeiger 1992). Numerous clinical trials attest to the efficacy of topical corticosteroids in controlling symptoms of allergic rhinitis (Juniper 1990; Seigel 1988). The similarity of the respiratory epithelium in the nose and paranasal sinuses, as well as the contiguity of these areas, would lead one to expect that sinusitis might also be treatable with inhaled corticosteroids.

Whether nasal steroid therapy can sufficiently decrease nasal inflammation and improve mucociliary transport to the point where the ostiomeatal complex becomes competent is unknown. Topical corticosteroids offer the theoretical advantage of a localised therapeutic action in nasal tissues, without the occurrence of undesirable systemic effects (Sahay 1980).
Inhaled corticosteroids have been used safely in patients with allergic rhinitis or asthma. There exists a theoretical concern regarding the potential spread of infection in acute sinusitis. However, this does not occur when topical corticosteroids are administered concurrently with antibiotics (Druce 1990; Druce 1991). Investigations of whether INCS promotes resolution of symptoms and prevents recurrences of sinusitis have yielded conflicting results (Meltzer 1993; Quarnberg 1992).

Acute sinusitis is a very common infection in childhood but its management remains a controversial issue. A considerable proportion of children, especially those with mild or improving symptoms, may not have to be treated at all (Contopoulos 2003). Management of acute sinusitis usually includes an oral antibiotic. However, it has been estimated that about $45 \%$ of cases will resolve without antibiotics (Spector 1998).

Considering the host of symptoms associated with acute rhinosinusitis, recovery can take time and be of substantial discomfort to the affected patient. The burden of affected individuals in terms of decreased productivity, absenteeism from the workplace and diminished quality of life, when added to the cost of care and the growing public health menace of antibioticresistant bacteria, makes rhinosinusitis a serious disease that warrants a precise diagnosis and effective therapy. Recognised pitfalls in acute rhinosinusitis management are the injudicious use of antibiotics and antihistamines (Winstead 2003). The decision on the best treatment for the specific patient should be based on the severity of symptoms, adapted individually, taking in consideration the existing evidence and the patient's preferences.

Most clinicians diagnose acute sinusitis using only clinical symptoms, without additional diagnostic tests. Over-diagnosis of acute bacterial rhinosinusitis is not surprising, considering the lack of specific clinical features that distinguish it from nonbacterial upper respiratory tract infections. Often, patients and physicians believe that an upper respiratory tract infection has gone on too long and that antibiotic treatment is therefore needed. Symptomatic treatment and reassurance are the preferred initial management strategy for patients with mild symptoms. Antibiotic therapy should be reserved for patients with severe symptoms who meet the criteria for the clinical diagnosis of acute bacterial rhinosinusitis, regardless of the duration of the illness. The greatest barrier to efficient antibiotic treatment of acute bacterial rhinosinusitis is the lack of a simple and accurate diagnostic test. Until a better test is widely available in clinical practice, the primary diagnosis of acute bacterial rhinosinusitis will remain imprecise (Snow 2001).

\section{Quality of the evidence}

Currently, nasal steroid therapy has become an acceptable adjunct in treating both acute and chronic sinusitis. Several intranasal steroids are now available: flunisolide, beclomethasone, triamcinolone, fluticasone, budesonide and mometasone. Each of these has proven to be effective in the treatment of allergic rhinitis and may be a useful addition in sinus disease (Spector 1998). The International Consensus Conference Proceedings on Rhinitis recommends the use of INCS as a first-line therapy, since they have been found to be well-tolerated and effective with minimal adverse events (Gawchik 2000). 
The evidence available suggests that some intranasal steroids, such as beclomethasone dipropionate, may slow growth when used regularly for prolonged periods (Allen 2000). Studies of MFNS in adults and children with allergic rhinitis showed a lack of hypothalamic-pituitary axis suppression, no childhood growth suppression and were consistent with extremely low bioavailability of MFNS after intranasal administration (Brannan 1997; Davies 1997; Schenkel 2000). Reducing the systemic activity of nasal corticosteroids to the lowest possible level is desirable. Pharmacologically, newer drugs such as MFNS and fluticasone propionate appear to have substantially higher topical potencies, higher lipid solubilities and lower systemic bioavailabilities than older compounds. With respect to adverse events, emerging data suggest that MFNS and fluticasone may have less potential for systemic effects during prolonged use, particularly in children (Corren 1999). For short-term therapy of one to two months, the first-generation INCS (beclomethasone, triamcinolone, budesonide and flunisolide) could be used and MFNS and fluticasone (second-generation drugs) could be considered for long-term therapy. With the exception of fluticasone for children aged four years and older and MFNS for those aged three years and older, the other INCS including beclomethasone, triamcinolone, budesonide and flunisolide are approved for children six years and older. All are effective, so the major considerations are cost and safety (Galant 2001).

The decision on the best treatment for the specific patient should be based on the severity of symptoms, adapted individually, taking in consideration the existing evidence and the patient's preferences.

\section{Potential biases in the review process}

A small number of studies were included in this review and not all reported an adequate concealment of allocation to treatment.

\section{Agreements and disagreements with other studies or reviews}

The minor effects of inhaled corticosteroids for acute sinusitis observed in this review are supported by other existing evidence, including the evidence mentioned here.

\section{AUTHORS' CONCLUSIONS}

\section{Implications for practice}

Current evidence supports the use of intranasal corticosteroids for relief or improvement in clinical outcomes in acute uncomplicated sinusitis, although data are limited and modest effects were observed. There is no evidence that their use as a monotherapy or as an adjuvant therapy would be detrimental in therapeutic doses. The study population included in this review was diagnosed both clinically and by radiology or endoscopy and is not necessarily identical to the participants from the clinical practice where the diagnosis is usually based on clinical signs and symptoms alone.

\section{Implications for research}

Given the small number of trials, additional large, randomised, placebo-controlled trials are needed to evaluate the efficacy of intranasal corticosteroids for acute sinusitis. These trials should describe adequate allocation and concealment procedures, be double-blinded and include outcomes on work performance, return to work and functional status, as well as assessment of different doses of INCS, the optimal duration of treatment and the risk-benefit ratio. Studies on participants with milder forms of acute sinusitis receiving symptomatic treatment including INCS and without antibiotic therapy could also be conducted, taking into consideration the emergence of resistant organisms and adverse events that result from the irrational use of antibiotics.

\section{ACKNOWLEDGEMENTS}

Thanks to the Cochrane Acute Respiratory Infections Group for ongoing assistance, especially Chanpen Choprapawon, Leonard Leibovici, Marilyn Oates, Richmal Oates-Whitehead and Erik Schenkel for useful comments on the draft protocol. We wish to thank Chanpen Choprapawon, Eric Schenkel, Richard G. Shoemaker and Leonard Leibovici for the commenting on the draft review and Liz Dooley and Sarah Thorning for the suggested search strategy and support with the searches and updates. We also wish to thank Yusra Adel Badr, JM Klossek, Sree Nair and Nick Matheson for commenting on the 2009 updated draft and Clalit Health Services Tel-Aviv district for supporting the activities of Anca Zalmanovici. 


\section{RE F E R E N C E S}

\section{References to studies included in this review}

Barlan 1997 \{published data only\}

Barlan IB, Erkan E, Bakir M, Berrak S, Basaran MM. Intranasal budesonide spray as an adjunct to oral antibiotic therapy for acute sinusitis in children. Annals of Allergy, Asthma \& Immunology 1997;78:598-601.

Dolor 2001 \{published data only\}

Dolor RJ, Witsell DL, Hellkamp AS, Williams JW, Califf RM, Simel DL. Comparison of cefuroxime with or without intranasal fluticasone for the treatment of rhinosinusitis. The CAFFS Trial: a randomized controlled trial. JAMA 2001;286:3097-105.

\section{Meltzer 2005 \{published data only\}}

Meltzer EO, Bachert C, Staudinger H. Treating acute rhinosinusitis: comparing efficacy and safety of mometasone furoate nasal spray, amoxicillin and placebo. Journal of Allergy and Clinical Immunology 2005;116(6):1289-95.

\section{Nayak 2002 \{published data only\}}

Nayak AS, Settipane GA, Pedinoff A, Charous BL, Meltzer EO, Busse WW, et al. Effective dose range of mometasone furoate nasal spray in the treatment of acute rhinosinusitis. Annals of Allergy, Asthma \& Immunology 2002;89:271-8.

\section{References to studies excluded from this review}

Bachert 2007 \{published data only\}

Bachert C, Meltzer EO. Effect of mometasone furoate nasal spray on quality of life of patients with acute rhinosinusitis. Rhinology 2007;45(3):190-6.

\section{Gehanno 2000 \{published data only\}}

Gehanno P, Beauvillain C, Bobin S, Chobaut JC, Desaulty A, Dubreuil $C$, et al. Short therapy with amoxicillin-clavulanate and corticosteroids in acute sinusitis: results of a multicentre study in adults. Scandinavian Journal of Infectious Diseases 2000;32:679-84.

\section{Jurkiewicz 2004 \{published data only\}}

Jurkiewicz D, Zielnik-Jurkiewicz B. Intranasal corticosteroid in the treatment of acute sinusitis. 5th European Congress of OtoRhino-Laryngology Head and Neck Surgery (EUFOS). 2004.

\section{Meltzer 1993 \{published data only\}}

Meltzer EO, Orgel HA, Backhaus JW, Busse WW, Druce HM, Metzger J, et al. Intranasal flunisolide spray as an adjunct to oral antibiotic therapy for sinusitis. Journal of Allergy and Clinical Immunology 1993;92:812-23.

\section{Meltzer 2000 \{published data only\}}

Meltzer EO, Charous BL, Busse WW, Zinreich SJ, Lorber RR, Danzig MR, et al. Added relief in the treatment of acute recurrent sinusitis with adjunctive mometasone furoate nasal spray. Journal of Allergy and Clinical Immunology 2000;106:630-7.
Quarnberg 1992 \{published data only\}

Quarnberg Y, Kantola O, Salo J, Toivanen M, Valtonen H, Vuori E. Influence of topical steroid treatment on maxillary sinusitis. Rhinology 1992;30:103-12.

Tutkun 1996 \{published data only\}

Tutkun A, Inanli S, Batman C, Uneri C, Sehitoglu MA. The impact of intranasal steroid as an adjunct to therapy for sinusitis. Marmara Medical Journal 1996;9(1):11-4.

\section{Williamson 2007 \{published data only\}}

Williamson IG, Rumsby K, Benge S, Moore M, Smith PW, Cross M, et al. Antibiotics and topical nasal steroid for treatment of acute maxillary sinusitis. JAMA 2007;298(21):2487-96.

Yilmaz 2000 \{published data only\}

Yilmaz G, Varan B, Yilmaz T, Gurakan B. Intranasal budesonide spray as an adjunct to oral antibiotic therapy for acute sinusitis in children. European Archives of Oto-rhino-laryngology 2000;257(5):256-9.

\section{Additional references}

\section{Ahovuo-Saloranta 2011}

Ahovuo-Saloranta A, Rautakorpi UM, Borisenko OV, Liira H, Williams Jr JW, Makela M. Antibiotics for acute maxillary sinusitis. Cochrane Database of Systematic Reviews 2011, Issue 3. [DOI: 10.1002/14651858.CD000243.pub2]

\section{Allen 2000}

Allen DB. Do intranasal corticosteroids affect childhood growth?. Allergy 2000;55(Suppl 62):15-8.

\section{Becker 2003}

Becker DG. Medical treatment of sinusitis. Journal of Long-term Effects of Medical Implants 2003;13(3):195-205.

\section{Benninger 1997}

Benninger MS, Anon J, Mabry RL. The medical management of rhinosinusitis. Otolaryngology - Head and Neck Surgery 1997;117(3 Pt 2):S41-9.

\section{Brannan 1997}

Brannan MD, Herron JM, Affrime MB. Safety and tolerability of once-daily mometasone furoate aqueous nasal spray in children. Clinical Therapeutics 1997;19:1330-9.

\section{Cable 2000}

Cable BB, Wassmuth Z, Mann EA, Hommer D, Connely G, Klem C, et al. The effect of corticosteroids in the treatment of experimental sinusitis. American Journal of Rhinology 2000;14(4):217-22.

\section{Contopoulos 2003}

Contopoulos-Ioannidis DG, loannidis JP, Lau J. Acute sinusitis in children: current treatment strategies. Paediatric Drugs 2003;5(2):71-80. 


\section{Corren 1999}

Corren J. Intranasal corticosteroids for allergic rhinitis: how do different agents compare?. Journal of Allergy and Clinical Immunology 1999;104(4 Pt 1):S144-9.

\section{Davies 1997}

Davies RJ, Nelson HS. Once-daily mometasone furoate nasal spray: efficacy and safety of a new intranasal glucocorticoid for allergic rhinitis. Clinical Therapeutics 1997;19:27-38.

\section{Druce 1990}

Druce HM. Adjuncts to medical management of sinusitis. Otolaryngology - Head and Neck Surgery 1990;103:880-3.

\section{Druce 1991}

Druce HM, Slavin RG. Sinusitis: critical need for further study. Journal of Allergy and Clinical Immunology 1991;88:675-7.

\section{Galant 2001}

Galant SP, Wilkinson R. Clinical prescribing of allergic rhinitis medication in the preschool and young school-age child: what are the options?. BioDrugs: Clinical Immunotherapeutics, Biopharmaceuticals and Gene Therapy 2001;15(7):453-63.

\section{Gawchik 2000}

Gawchik SM, Saccar CL. A risk-benefit assessment of intranasal triamcinolone acetonide in allergic rhinitis. Drug Safety 2000;23(4):309-22.

\section{Gwaltney 1994}

Gwaltney JM, Phillips CD, Miller RD, Riker DK. Computed tomographic study of the common cold. New England Journal of Medicine 1994;330(1):25-30.

\section{Gwaltney 1995}

Gwaltney JM Jr, Jones JG, Kennedy DW. Medical management of sinusitis: educational goals and management guidelines: the International Conference on Sinus Disease. Annals of Otology, Rhinology and Laryngology Supplement 1995;167:22-30.

\section{Higgins 2011}

Higgins JPT, Green S (editors). Cochrane Handbook for Systematic Reviews of Interventions Version 5.1.0 [updated March 2011]. The Cochrane Collaboration, 2011. Available from www.cochrane-handbook.org. Chichester, UK: Wiley-Blackwell.

\section{Juniper 1990}

Juniper EF, Guyatt GH, O'Byrne PM, Viveiros M. Aqueous beclomethasone dipropionate nasal spray: regular versus "as required" use in the treatment of seasonal allergic rhinitis. Journal of Allergy and Clinical Immunology 1990;86:380-6.

\section{Kaliner 1997}

Kaliner MA, Osguthorpe JD, Fireman P, Anon J, Georgitis J, Davis ML, et al. Sinusitis: bench to bedside. Current findings, future directions. Journal of Allergy and Clinical Immunology 1997;99(Suppl):829-48.

\section{Lefebvre 2011}

Lefebvre C, Manheimer E, Glanville J. Chapter 6: Searching for studies. In: Higgins JPT, Green S editor(s). Cochrane Handbook for Systematic Reviews of Interventions. Version 5.1.0 [updated March 2011]. The Cochrane Collaboration. Available from www.cochrane-handbook.org. Chichester: Wiley-Blackwell, 2011.

\section{Little 2000}

Little DR, Mann BL, Godbout CJ. How family physicians distinguish acute sinusitis from upper respiratory tract infections: a retrospective analysis. Journal of the American Board of Family Practice 2000;13(2):101-6.

\section{Mucha 2003}

Mucha SM, Baroody FM. Sinusitis update. Current Opinion in Allergy and Clinical Immunology 2003;3(1):33-8.

\section{Mygind 1976}

Mygind N, Prytz S, Sorensen H, Pedersen CB. Long term treatment of nasal polyps with beclomethasone dipropionate aerosol. Treatment and rationale. Acta Otolaryngologica (Stockholm) 1976;82:252-5.

\section{Mygind 2001}

Mygind N, Nielsen LP, Hoffmann HJ, Shukla A, Blumberga G, Dahl R, et al. Mode of action of intranasal corticosteroids. Journal of Allergy and Clinical Immunology 2001;108(Suppl 1):16-25.

\section{Piccirillo 2001}

Piccirillo JF, Mager D, Frisse M, Brophy RH, Goggin A. Impact of first-line vs. second-line antibiotics for the treatment of acute uncomplicated sinusitis. JAMA 2001;286(15):1849-56.

\section{RevMan 2012 [Computer program]}

The Nordic Cochrane Centre, The Cochrane Collaboration. Review Manager (RevMan). Version 5.2. Copenhagen: The Nordic Cochrane Centre, The Cochrane Collaboration, 2012.

\section{Sahay 1980}

Sahay JN, Ibrahim NBN, Chatterjee SS, Nassar WY, Lodge KV, Jones CW. Long term study of flunisolide treatment in perennial rhinitis with special reference to nasal mucosal histology and morphology. Clinical Allergy 1980;10:451-7.

\section{Scadding 2000}

Scadding GK. Other anti-inflammatory uses of intranasal corticosteroids in upper respiratory inflammatory diseases. Allergy 2000;55(Suppl 62):19-23.

\section{Schenkel 2000}

Schenkel EJ, Skoner DP, Bronsky EA, Miller SD, Pearlman DS, Rooklin A. Absence of growth retardation in children with perennial allergic rhinitis after one year of treatment with mometasone furoate aqueous nasal spray. Pediatrics 2000;105:E22.

\section{Seigel 1988}

Seigel SC. Topical intranasal corticosteroid therapy in rhinitis. Journal of Allergy and Clinical Immunology 1988;81:984-91. 


\section{Shaikh 2012}

Shaikh N, Wald ER, Pi M. Decongestants, antihistamines and nasal irrigation for acute sinusitis in children. Cochrane Database of Systematic Reviews 2012, Issue 9. [DOI: 10.1002/14651858.CD007909.pub3]

\section{Shapiro 1992}

Shapiro GG, Rachelefski GS. Introduction and definition of sinusitis. Journal of Allergy and Clinical Immunology 1992;90:417-8

\section{Shrum 2001}

Shrum KM, Grogg SE, Barton P, Shaw HH, Dyer RR. Sinusitis in children: the importance of diagnosis and treatment. Journal of the American Osteopathic Association 2001;101(Suppl 5):8-13.

\section{Slavin 2005}

Slavin RG, Spector SL, Bernstein IL, Kaliner MA, Kennedy DW, Virant FS, et al. The diagnosis and management of sinusitis: a practice parameter update. Journal of Allergy and Clinical Immunology 2005;116(Suppl 6):13-47.

\section{Snow 2001}

Snow V, Mottur-Pilson C, Hickner JM. Principles of appropriate antibiotic use for acute sinusitis in adults. Annals of International Medicine 2001;134(6):495-7.

\section{Spector 1998}

Spector SL, Bernstein IL, Li JT, Berger WE, Kaliner MA, Schuller DE, et al. Parameters for the diagnosis and management of sinusitis. Journal of Allergy and Clinical Immunology 1998;102(Suppl):107-44.

\section{Venekamp 2011}

Venekamp RP, Thompson MJ, Hayward G, Heneghan CJ, Del Mar CB, Perera R, et al. Systemic corticosteroids for acute sinusitis. Cochrane Database of Systematic Reviews 2011, Issue 12. [DOI: 10.1002/14651858.CD008115.pub2]

\section{CHARACTERISTICS OF STUDIES}

Characteristics of included studies [ordered by study ID]

\section{Wald 1988}

Wald ER. Sinusitis in children. Pediatric Infectious Disease Journal 1988;7(Suppl 11):150-3.

\section{Williams 1993}

Williams JW Jr, Simel DL. Practice variation for managing acute sinusitis. Clinical Research 1993;41:566A.

\section{Winstead 2003}

Winstead W. Rhinosinusitis. Primary Care 2003;30(1):137-54.

\section{Winther 1990}

Winther B, Gwaltney JM Jr. Therapeutic approach to sinusitis: antiinfectious therapy as the baseline of management. Otolaryngology - Head and Neck Surgery 1990;103(5 (Pt 2)):876-9.

\section{Zeiger 1992}

Zeiger RS. Prospects for ancillary treatment of sinusitis in the 1990s. Journal of Allergy and Clinical Immunology 1992;90:478-95.

\section{References to other published versions of this review}

\section{Zalmanovici 2007}

Zalmanovici A, Yaphe J. Steroids for acute sinusitis. Cochrane Database of Systematic Reviews 2007, Issue 2. [DOI: 10.1002/14651858.CD005149.pub2]

\section{Zalmanovici 2009}

Zalmanovici A, Yaphe J. Intranasal steroids for acute sinusitis. Cochrane Database of Systematic Reviews 2009, Issue 4. [DOI: 10.1002/14651858.CD005149.pub3]

\section{Zalmanovici Trestioreanu 2011}

Zalmanovici Trestioreanu A, Yaphe J. Intranasal steroids for acute sinusitis. Cochrane Database of Systematic Reviews 2011, Issue 8. [DOI: 10.1002/14651858.CD005149.pub3]

Barlan 1997

\begin{tabular}{ll}
\hline Methods & Randomised: method of randomisation not mentioned \\
& Allocation concealment not mentioned \\
Double-blind: yes \\
Intention-to-treat not mentioned \\
Follow-up described \\
151 recruited; $89(59 \%)$ completed study; $41 \%$ drop-out \\
Design: parallel
\end{tabular}


Barlan 1997 (Continued)

Exclusion criteria: history of allergic rhinitis, asthma, recurrent/chronic sinusitis

Baseline characteristics: similar in both groups, no significant differences

Patients maintained daily symptom cards and were examined by the same physician each week.

Symptom scores were evaluated by a scale from 0 to 3

\begin{tabular}{ll}
\hline Outcomes & $\begin{array}{l}\text { Difference in weekly symptom scores for cough and nasal discharge in the first, second and third week } \\
\text { of the study in both groups, as difference between groups or change from baseline } \\
\text { Relapse: results were reported as medians of scores using non-parametric tests because a wide range } \\
\text { of scores without normal distribution }\end{array}$ \\
\hline Notes & $\begin{array}{l}\text { Marmara University Hospital Outpatient Clinic patients enrolled from November } 1993 \text { to October } 1994 \\
\text { Informed consent signed by all parents. } 151 \text { patients enrolled, } 89 \text { completed study, } 62 \text { dropped out, no } \\
\text { separate data for both groups } \\
\text { Reasons for drop-outs: non-compliance with weekly visits or not recording daily symptoms }\end{array}$
\end{tabular}

\section{Risk of bias}

\begin{tabular}{|c|c|c|}
\hline Bias & Authors' judgement & Support for judgement \\
\hline $\begin{array}{l}\text { Random sequence genera- } \\
\text { tion (selection bias) }\end{array}$ & Unclear risk & Randomised, method not mentioned \\
\hline $\begin{array}{l}\text { Allocation concealment } \\
\text { (selection bias) }\end{array}$ & Unclear risk & Not mentioned \\
\hline $\begin{array}{l}\text { Incomplete outcome data } \\
\text { (attrition bias) } \\
\text { All outcomes }\end{array}$ & Unclear risk & No separate data for groups, ITT not mentioned \\
\hline $\begin{array}{l}\text { Selective reporting (re- } \\
\text { porting bias) }\end{array}$ & Low risk & No evidence of reporting bias \\
\hline Other bias & Unclear risk & - \\
\hline $\begin{array}{l}\text { Blinding of participants } \\
\text { and personnel (perfor- } \\
\text { mance bias) } \\
\text { All outcomes }\end{array}$ & Low risk & Double-blind \\
\hline $\begin{array}{l}\text { Blinding of outcome as- } \\
\text { sessment (detection bias) } \\
\text { All outcomes }\end{array}$ & Unclear risk & - \\
\hline
\end{tabular}

\section{Dolor 2001}

$\begin{array}{ll}\text { Methods } & \text { Multicentre randomisation - permuted blocks scheme stratified by site with a block size of } 4 \text { generated } \\ \text { using SAS version } 6.12 & \\ \text { Allocation concealment - study kits administered sequentially by blinding site personnel to block size } & \text { Blinding: yes } \\ \text { Intention-to-treat: yes } \\ \text { Follow-up described: yes } \\ 88(93 \%) \text { completed study }\end{array}$


Dolor 2001 (Continued)

Design: parallel

Participants
Age 30 to 50 ; median age 39 years
Inclusion criteria: older than 18 years, history of recurrent sinusitis or chronic rhinitis and clinical evi-
dence of acute sinusitis confirmed Rx or by nasal endoscopy
Diagnosis of acute sinusitis: clinical criteria - participants with 2 of the 5 following symptoms present
were enrolled: headache, facial pain, nasal congestion, thick coloured nasal discharge, olfactory distur-
bance
Rx criteria: air-fluid level, mucosal thickening or opacification of sinus
Exclusion criteria: previous sinus surgery, sinus lavage in the past 7 days, nasal polyposis, recur-
rent epistaxis, chronic bacterial sinusitis with failure of antibiotic therapy, INCS use within past 14
days, chronic use of corticosteroids or immunosuppressives, immunocompromised, allergy to peni-
cillin/cephalosporins, participants without a telephone, pregnant, nursing women
Baseline characteristics - similar in both groups, no significant differences
Participants assessed at baseline, 10, 21, 56 days by diary records and telephone follow-up

Interventions

Tx group: nasal spray fluticasone propionate 2 puffs (total dose $200 \mu \mathrm{g}$ ) once daily in each nostril; $\mathrm{N}=47$ C group: nasal spray placebo 2 puffs once daily in each nostril; $N=48$

All participants in both groups received 2 puffs xylometazoline hydrochloride in each nostril twice daily

10 minutes before the study nasal spray and $250 \mathrm{mg}$ cefuroxime axetil twice daily for 10 days

Duration of study: 21 days

Follow-up: 8 weeks

Allowed to continue: NSAIDs, analgesics, immunotherapy for allergies, orally inhaled corticosteroids

Not permitted during study: oral decongestants, mucolytics, corticosteroids oral or parenteral, antihistamines, immunosuppressives

Sinus lavage or sinus surgery was discouraged during the first 3 weeks of the trial, antibiotic use in the past 7 days or 21 days if longer half-life was not permitted

Compliance with Tx: assessed by a standardised form given to patients for recording daily symptoms, Tx, adverse events, work attendance. 94\% completed study Tx without difference between groups

Outcomes

Proportion of patients with clinical success (cured or much improved) at 10,21, 56 days on telephone follow-up

Time to clinical success differences over time in sinusitis and quality of life scores

Level of work performance

Total number of hours lost from work

Recurrences

\section{Notes}

Study conducted between October 1998 to April 2000 at 22 sites (12 primary care and 10 otolaryngology)

Equal proportions of participants from primary care and otolaryngology practices in both treatment arms

All study sites received standardised instructions for conducting the study

Study progress monitored by a research associate

Patients assessed symptoms on numeric scales and received booklets with specific instructions for use of nasal spray

High agreement between patient-recorded and interviewer-obtained symptoms

Drop-outs:

Tx group: 1 - rash, 1 - unknown, 1 - lost to follow-up

44 completed 21-day Tx and telephone follow-up, 36 completed diary, 46 included in primary analysis

C group: 1 - withdrew, 2 - switched to different antibiotics

45 completed 21-day Tx, 44 completed telephone follow-up, 32 completed diary, 46 included in primary analysis

\section{Risk of bias}

Bias Authors' judgement Support for judgement


Dolor 2001 (Continued)

\begin{tabular}{|c|c|c|}
\hline $\begin{array}{l}\text { Random sequence genera- } \\
\text { tion (selection bias) }\end{array}$ & Low risk & See methods \\
\hline $\begin{array}{l}\text { Allocation concealment } \\
\text { (selection bias) }\end{array}$ & Low risk & See methods \\
\hline $\begin{array}{l}\text { Incomplete outcome data } \\
\text { (attrition bias) } \\
\text { All outcomes }\end{array}$ & Low risk & See methods \\
\hline $\begin{array}{l}\text { Selective reporting (re- } \\
\text { porting bias) }\end{array}$ & Low risk & No evidence of selective reporting \\
\hline Other bias & Low risk & - \\
\hline $\begin{array}{l}\text { Blinding of participants } \\
\text { and personnel (perfor- } \\
\text { mance bias) } \\
\text { All outcomes }\end{array}$ & Unclear risk & See methods \\
\hline
\end{tabular}

Blinding of outcome as- Unclear risk

sessment (detection bias)

All outcomes

\section{Meltzer 2005}

\begin{tabular}{|c|c|}
\hline Methods & $\begin{array}{l}\text { Multicentre randomisation } \\
\text { 1:1:1:1 ratio to } 1 \text { of } 4 \text { arms by computer-generated code } \\
\text { Allocation concealment: not mentioned } \\
\text { Double-blind: yes } \\
\text { Intention-to-treat: yes } \\
\text { Follow-up described } \\
\text { 10\% drop-out in Tx phase, } 95 \% \text { completed follow-up phase } \\
\text { Design: parallel }\end{array}$ \\
\hline Participants & $\begin{array}{l}\mathrm{N}=981 ; 338 \text { men, } 643 \text { women } \\
\text { Age } 12 \text { to } 76 \text { years } \\
\text { Inclusion criteria: age more than } 12 \text { years with clinical criteria for acute sinusitis; MSS more than } 5 \text { but } \\
\text { less than } 12 \text { at baseline, assessed by participant and investigator and no more than } 3 / 5 \text { symptoms rat- } \\
\text { ed severe (rhinorrhoea, PND nasal congestion, stuffiness, sinus headache and facial pain on pressure) } \\
\text { adding cough to the TSS } \\
\text { Exclusion criteria: fulminant bacterial rhinosinusitis, chronic rhinosinusitis, nasal/sinus surgery within } \\
\text { the last } 6 \text { months for this condition, otitis, atrophic rhinitis, nasal polyps, symptomatic seasonal aller- } \\
\text { gic rhinitis, allergy to corticosteroids } \\
\text { Asthmatic participants needed to be stable last } 30 \text { days and FEV1 more than } 65 \% \text { last } 3 \text { months before } \\
\text { screening } \\
\text { Rhinoscopic examination was performed at all visits } \\
\text { Participants were assessed at baseline days } 8,15,29 \text { and monitored by telephone on days } 3 \text { to } 4 \text {. Re- } \\
\text { sponse to Tx evaluated by participant and investigator as scores for symptoms on a scale from } 0 \text { to } 3 \\
\text { Baseline characteristics similar for all the arms }\end{array}$ \\
\hline Interventions & $\begin{array}{l}\text { 4 groups } \\
\text { Tx groups: } \\
\text { 1. MFNS } 200 \mu \text { g once daily nasal spray + placebo nasal spray once daily + placebo capsules tid; } N=243 \\
\text { 2. MFNS } 200 \mu \mathrm{g} \text { nasal spray bid + placebo capsules tid; } N=235 \\
\text { 3. amoxicillin } 500 \mathrm{mg} \text { tid for } 10 \text { days + placebo nasal spray bid; } N=251 \\
\text { C group: placebo nasal spray bid + placebo capsules tid; } N=252\end{array}$ \\
\hline
\end{tabular}


Meltzer 2005 (Continued)

Duration of study: 15 days

Capsules given for 10 days

Follow-up: 14 days

Not allowed during study: nasal saline, nasal cromolyn sodium, ipratropium bromide, corticosteroids

(excluding oral inhaled corticosteroids for mild/moderate asthma), antihistamines, decongestants,

leukotriene pathway modificants, analgesics, NSAID

Compliance assessed at days 8 and 15 by questioning whether drug had been taken

Each participant received at least 1 dose of study drug

\begin{tabular}{ll}
\hline Outcomes & Mean MSS \\
Mean TSS \\
Individual scores \\
Time to onset of action \\
Global response to Tx \\
Adverse events \\
Disease recurrence \\
Tx failure (worsening or not improvement in symptoms during the Tx phase)
\end{tabular}

Notes

Study conducted at 71 medical centres in 14 countries from January to September 2003

Drop-outs: during the Tx phase in the $200 \mu \mathrm{g}, 400 \mu \mathrm{g}$ MFNS, amoxicillin, placebo were 9\%, 9\%, 8\%, 13\%

Reasons for discontinuation: adverse events, Tx failure, loss to follow-up, did not wish to continue, non-compliance with protocol, did not meet protocol criteria for entry

\section{Risk of bias}

\begin{tabular}{|c|c|c|}
\hline Bias & Authors' judgement & Support for judgement \\
\hline $\begin{array}{l}\text { Random sequence genera- } \\
\text { tion (selection bias) }\end{array}$ & Low risk & See methods \\
\hline $\begin{array}{l}\text { Allocation concealment } \\
\text { (selection bias) }\end{array}$ & Unclear risk & See methods \\
\hline $\begin{array}{l}\text { Incomplete outcome data } \\
\text { (attrition bias) } \\
\text { All outcomes }\end{array}$ & Low risk & See methods \\
\hline $\begin{array}{l}\text { Selective reporting (re- } \\
\text { porting bias) }\end{array}$ & Low risk & - \\
\hline Other bias & Unclear risk & - \\
\hline $\begin{array}{l}\text { Blinding of participants } \\
\text { and personnel (perfor- } \\
\text { mance bias) } \\
\text { All outcomes }\end{array}$ & Unclear risk & See methods \\
\hline
\end{tabular}

Blinding of outcome assessment (detection bias)

Unclear risk

All outcomes

Nayak 2002

$\begin{array}{ll}\text { Methods } & \text { Multicentre, randomised; method of randomisation not mentioned } \\ & \text { Allocation concealment not mentioned } \\ & \text { Double-blind: yes } \\ & \text { Follow-up described: yes }\end{array}$


Nayak 2002 (Continued)

864 (89\%) participants included in the primary efficacy analysis

Design: parallel

Participants
Age 8 to 78 years
Inclusion criteria: acute episode of rhinosinusitis, at least 1 moderate/severe nasal symptom (these
may include purulent rhinorrhoea, stuffiness/congestion, post-nasal drip, sinus headache, facial pain,
cough), purulent rhinorrhoea present, sinusitis confirmed by a CT scan, which is read by a radiologist at
each study site at baseline, a total symptom score more than 6
Exclusion criteria: nasal polyps, cystic fibrosis, Kartagener syndrome, expected immediate sinus or
nasal surgery, glaucoma, history of subcapsular cataracts, clinical significant diseases
Symptoms evaluated at baseline (day 1 ) and day 21 by patient and investigator by scales. Patients
evaluated at baseline, 15, 21 days
CT scans of paranasal sinuses at baseline and 21 days evaluated by an independent blinded radiologist
Similar baseline characteristics and baseline symptoms scores in all 3 groups
Patients recorded symptom scores, adverse events and use of medication twice daily
3 groups
Tx groups:
1 MFNS $400 \mu \mathrm{g}$ nasal spray twice daily; $\mathrm{N}=324$
2 MFNS $200 \mu \mathrm{\mu g}$ nasal spray twice daily; $\mathrm{N}=318$
C group:
Matching placebo nasal spray twice daily; $\mathrm{N}=325$
All participants in all groups received amoxicillin-clavulanate potassium 875 mg twice daily for 21 days
Not allowed during study: any form of corticosteroid, nasal decongestants, antihistamines
Washout period before the baseline visit for previous use of antibiotics, intranasal or systemic corticos-
teroids, decongestants
Adherence to therapy assessed by weighing the nasal spray dosing containers without patients' knowl-
edge

$\begin{array}{ll}\text { Outcomes } & \text { Improvement in total symptoms score } \\ \text { Improvement in individual symptom score } \\ \text { Overall response to treatment: proportion of participants with complete or marked relief } \\ \text { Onset of relief } \\ \text { Evaluation of changes in CT scans of sinuses } \\ \text { Adverse events }\end{array}$

Notes Outpatients from 61 Tx centres in the US

967 participants randomised, 103 participants (11\%) not included in analysis because CT did not confirm sinusitis and excluded post-randomisation, diary data not available, less than $80 \%$ compliance with Tx, less than 7 days Tx (32, 36, 35 in the MFNS 400, $200 \mu \mathrm{g}$ and placebo groups) Reasons for exclusion or discontinuation were evenly distributed among the groups Physician evaluation of symptoms at day 21 was consistent with patient-recorded evaluation

\section{Risk of bias}

\begin{tabular}{lll}
\hline Bias & Authors' judgement & Support for judgement \\
\hline $\begin{array}{l}\text { Random sequence genera- } \\
\text { tion (selection bias) }\end{array}$ & Unclear risk & See methods \\
\hline $\begin{array}{l}\text { Allocation concealment } \\
\text { (selection bias) }\end{array}$ & Unclear risk & See methods \\
\hline $\begin{array}{l}\text { Incomplete outcome data } \\
\text { (attrition bias) } \\
\text { All outcomes }\end{array}$ & Unclear risk & See notes \\
\hline
\end{tabular}


Nayak 2002 (Continued)

\begin{tabular}{lll}
$\begin{array}{l}\text { Selective reporting (re- } \\
\text { porting bias) }\end{array}$ & Unclear risk & \\
\hline Other bias & Unclear risk & - \\
\hline $\begin{array}{l}\text { Blinding of participants } \\
\text { and personnel (perfor- } \\
\text { mance bias) }\end{array}$ & Low risk & See methods \\
All outcomes & &
\end{tabular}

Blinding of outcome as-
sessment (detection bias)
All outcomes

bid: twice daily

C: control

CT: computed tomography

FEV1: forced expiratory volume in one second

INCS: intranasal corticosteroid

ITT: intention-to-treat

MFNS: mometasone furoate

MSS: major symptom score

NSAID: non-steroidal anti-inflammatory drugs

PND: post-nasal drip

Rx: radiological

tid: three times daily

TSS: total symptom score

Tx: treatment

Characteristics of excluded studies [ordered by study ID]

\begin{tabular}{ll}
\hline Study & Reason for exclusion \\
\hline Bachert 2007 & $\begin{array}{l}\text { Study on quality of life. Outcome for a subset of patients from one of the included studies (Meltzer } \\
\text { 2005) }\end{array}$ \\
\hline Gehanno 2000 & $\begin{array}{l}\text { Allocation: randomised, parallel } \\
\text { Participants: } \mathrm{N}=433 \text { adults with confirmed acute sinusitis } \\
\text { Intervention: amoxicillin-clavulanate and methylprednisolone or placebo per oral administration } \\
\text { No intranasal steroids used }\end{array}$ \\
\hline Jurkiewicz 2004 & Abstract and full paper not available \\
\hline Meltzer 1993 & $\begin{array}{l}\text { Allocation: randomised, parallel } \\
\text { Participants: } \mathrm{N}=175 \text { participants } 14 \text { years or older with confirmed acute or chronic sinusitis } \\
\text { Intervention: amoxicillin-clavulanate potassium combined with nasal spray of either flunisolide or } \\
\text { placebo } \\
\text { No separate arms for acute and chronic sinusitis reported }\end{array}$ \\
\hline
\end{tabular}

Meltzer 2000

Missing data - number randomised, numbers included in analyses, drop-outs and reasons for dropout. The numbers reported do not add up to $100 \%$. An email was sent to the author but there was no reply

Quarnberg 1992

Allocation: randomised, parallel

Participants: $\mathrm{N}=40$ participants 16 years or older with confirmed recurrent or chronic sinusitis Intervention: erythromycin and either budesonide or placebo aerosol 


\begin{tabular}{ll}
\hline Study & Reason for exclusion \\
\hline Separate arms for acute recurrent and chronic sinusitis were not reported \\
\hline Tutkun 1996 & $\begin{array}{l}\text { Missing data - not mentioned acute/chronic sinusitis, diagnostic criteria not reported, drop-outs } \\
\text { not reported. Email was sent to the author but there was no reply }\end{array}$ \\
\hline Inclusion criteria for the review were not met \\
\hline Yilmaz 2000 & $\begin{array}{l}\text { Allocation: randomised, parallel } \\
\text { Participants: } 52 \text { children with confirmed acute sinusitis } \\
\text { Intervention: cefaclor and either oral pseudoephedrine or intranasal budesonide } \\
\text { No placebo used in the control group }\end{array}$ \\
\hline
\end{tabular}

DATA AND ANALYSES

Comparison 1. Intranasal corticosteroids versus placebo

\begin{tabular}{|c|c|c|c|c|}
\hline Outcome or subgroup title & $\begin{array}{l}\text { No. of } \\
\text { studies }\end{array}$ & $\begin{array}{l}\text { No. of } \\
\text { partici- } \\
\text { pants }\end{array}$ & Statistical method & Effect size \\
\hline $\begin{array}{l}1 \text { Proportion of participants with resolution of symp- } \\
\text { toms or improved (MFNS } 400 \mu \mathrm{g} \text { daily) }\end{array}$ & 2 & 1130 & $\begin{array}{l}\text { Risk Ratio (M-H, Fixed, 95\% } \\
\mathrm{Cl})\end{array}$ & $\begin{array}{l}1.10[1.02, \\
1.18]\end{array}$ \\
\hline $\begin{array}{l}2 \text { Proportion of participants with resolution of symp- } \\
\text { toms or improved (MFNS } 200 \text { mg daily) }\end{array}$ & 2 & 590 & $\begin{array}{l}\text { Risk Ratio (M-H, Fixed, 95\% } \\
\mathrm{Cl})\end{array}$ & $\begin{array}{l}1.04[0.98, \\
1.11]\end{array}$ \\
\hline $\begin{array}{l}3 \text { Proportion of participants with resolution of symp- } \\
\text { toms or improved (combined MFNS 200, } 400 \text { and } 800 \mu \mathrm{g} \\
\text { daily) }\end{array}$ & 3 & 1792 & $\begin{array}{l}\text { Risk Ratio (M-H, Fixed, 95\% } \\
\mathrm{Cl})\end{array}$ & $\begin{array}{l}1.11[1.04, \\
1.18]\end{array}$ \\
\hline $\begin{array}{l}4 \text { Number of participants that dropped out from the } \\
\text { study (MFNS } 400 \mu \text { g daily) }\end{array}$ & 2 & 1130 & $\begin{array}{l}\text { Risk Ratio (M-H, Fixed, 95\% } \\
\mathrm{Cl})\end{array}$ & $\begin{array}{l}0.86[0.61 \\
1.20]\end{array}$ \\
\hline $\begin{array}{l}5 \text { Number of participants that dropped out from the } \\
\text { study (MFNS } 200 \mu \text { g daily) }\end{array}$ & 2 & 590 & $\begin{array}{l}\text { Risk Ratio (M-H, Fixed, 95\% } \\
\mathrm{Cl})\end{array}$ & $\begin{array}{l}0.75[0.46 \\
1.21]\end{array}$ \\
\hline $\begin{array}{l}6 \text { Number of participants that dropped out from the } \\
\text { study (combined MFNS 200, } 400 \text { and } 800 \mu \text { g daily) }\end{array}$ & 3 & 1792 & $\begin{array}{l}\text { Risk Ratio (M-H, Fixed, 95\% } \\
\mathrm{Cl})\end{array}$ & $\begin{array}{l}0.85[0.64, \\
1.12]\end{array}$ \\
\hline 7 Relapse (combined 200 and $400 \mu \mathrm{g}$ daily) & 2 & 825 & $\begin{array}{l}\text { Risk Ratio (M-H, Fixed, 95\% } \\
\mathrm{Cl} \text { ) }\end{array}$ & $\begin{array}{l}0.71[0.44 \\
1.15]\end{array}$ \\
\hline
\end{tabular}

Analysis 1.1. Comparison 1 Intranasal corticosteroids versus placebo, Outcome 1 Proportion of participants with resolution of symptoms or improved (MFNS $400 \mu \mathrm{g}$ daily).

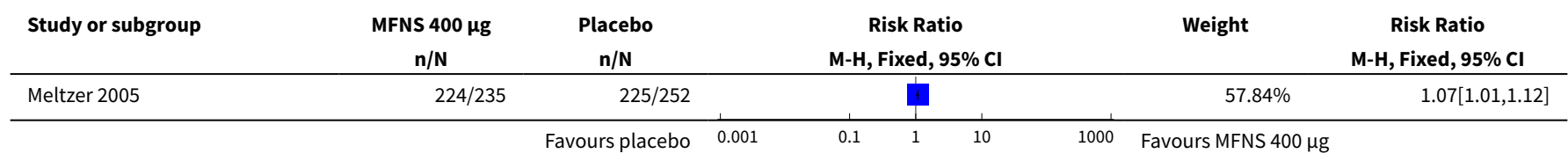




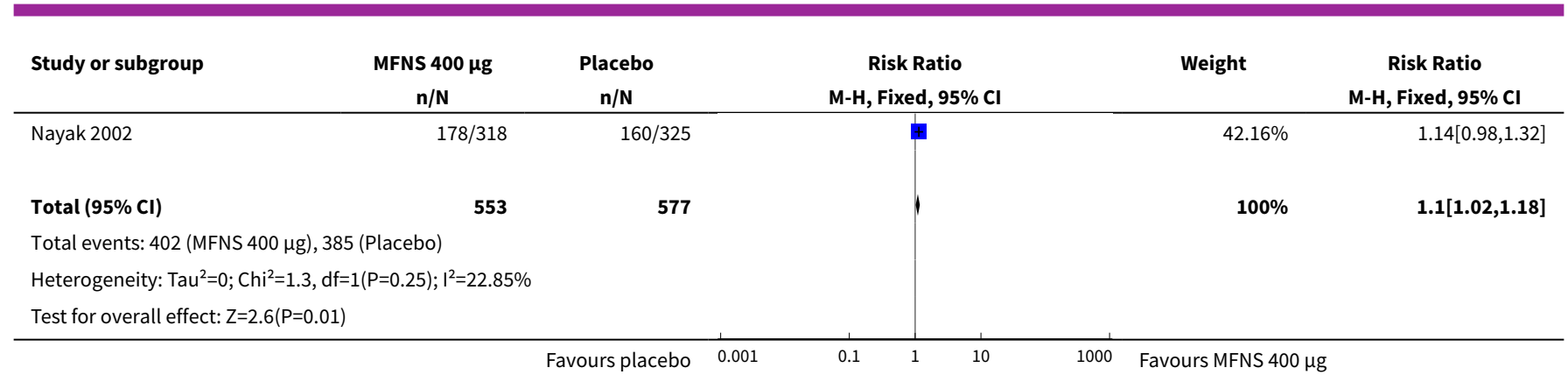

Analysis 1.2. Comparison 1 Intranasal corticosteroids versus placebo, Outcome 2 Proportion of participants with resolution of symptoms or improved (MFNS $200 \mu \mathrm{g}$ daily).

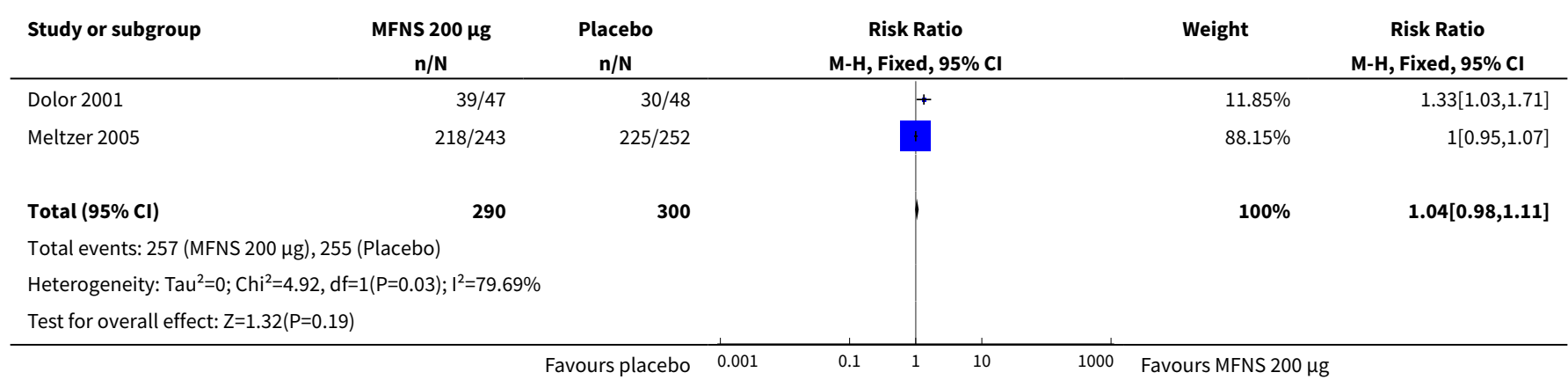

Analysis 1.3. Comparison 1 Intranasal corticosteroids versus placebo, Outcome 3 Proportion of participants with resolution of symptoms or improved (combined MFNS 200, 400 and $800 \mu \mathrm{g}$ daily).

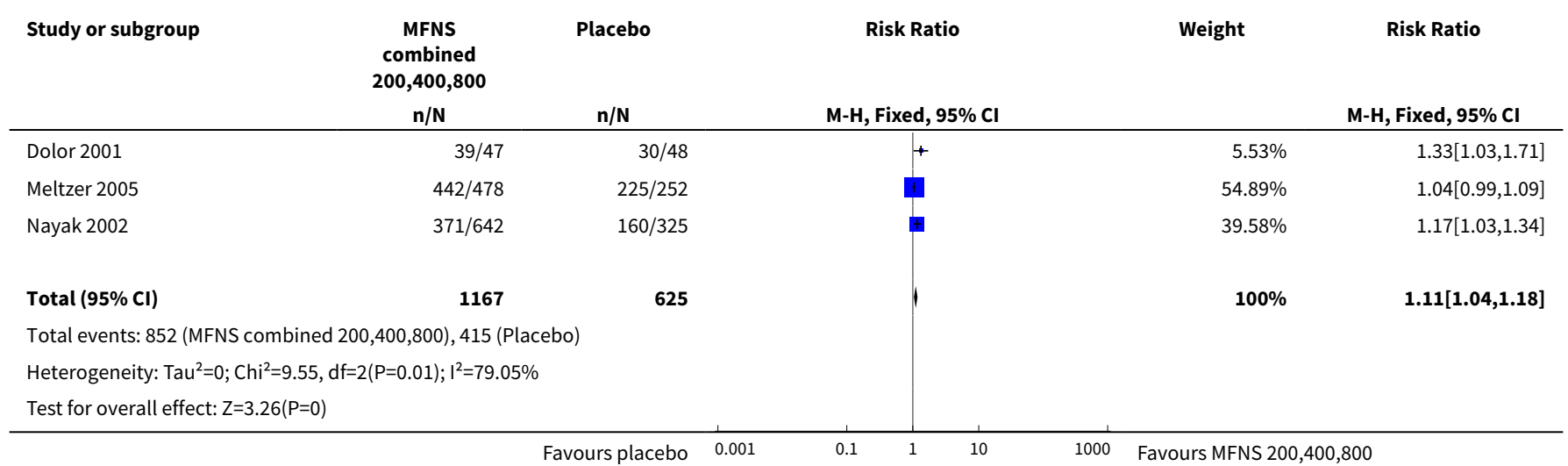

Analysis 1.4. Comparison 1 Intranasal corticosteroids versus placebo, Outcome

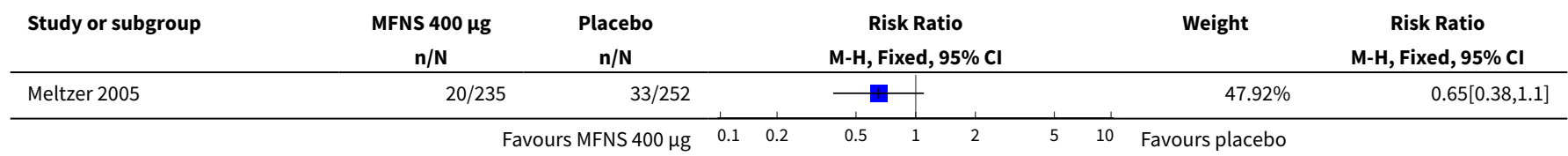




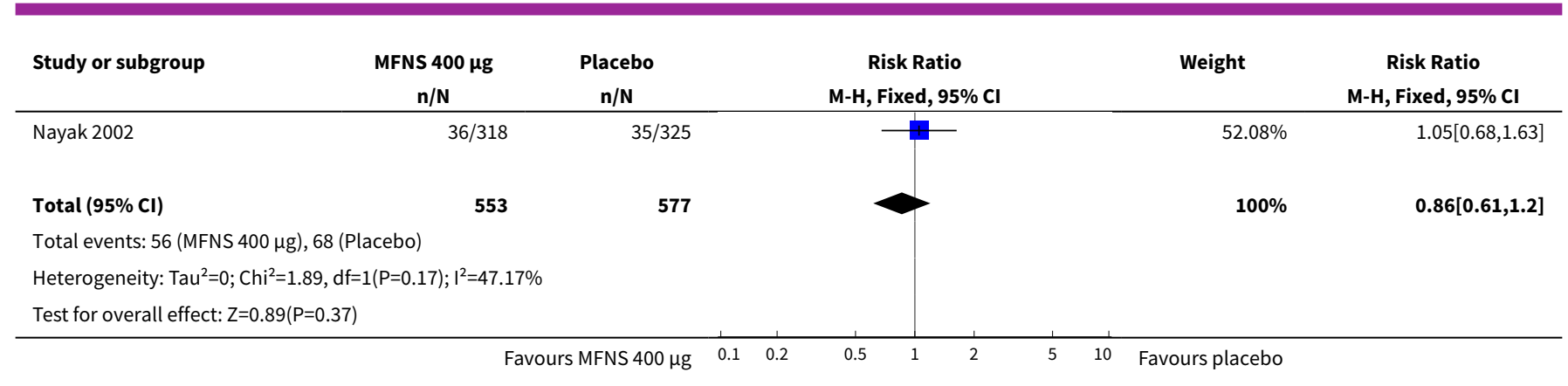

Analysis 1.5. Comparison 1 Intranasal corticosteroids versus placebo, Outcome 5 Number of participants that dropped out from the study (MFNS $200 \mu \mathrm{g}$ daily).



Analysis 1.6. Comparison 1 Intranasal corticosteroids versus placebo, Outcome 6 Number of participants that dropped out from the study (combined MFNS 200, 400 and $800 \mu \mathrm{g}$ daily).

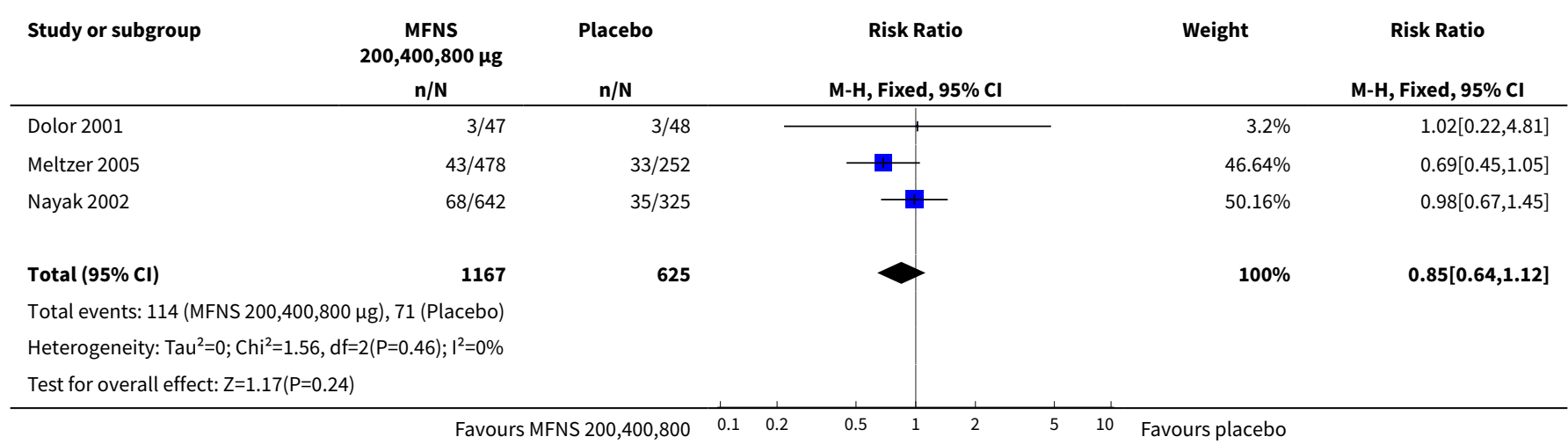

Analysis 1.7. Comparison 1 Intranasal corticosteroids versus placebo, Outcome 7 Relapse (combined 200 and $400 \mu \mathrm{g}$ daily).






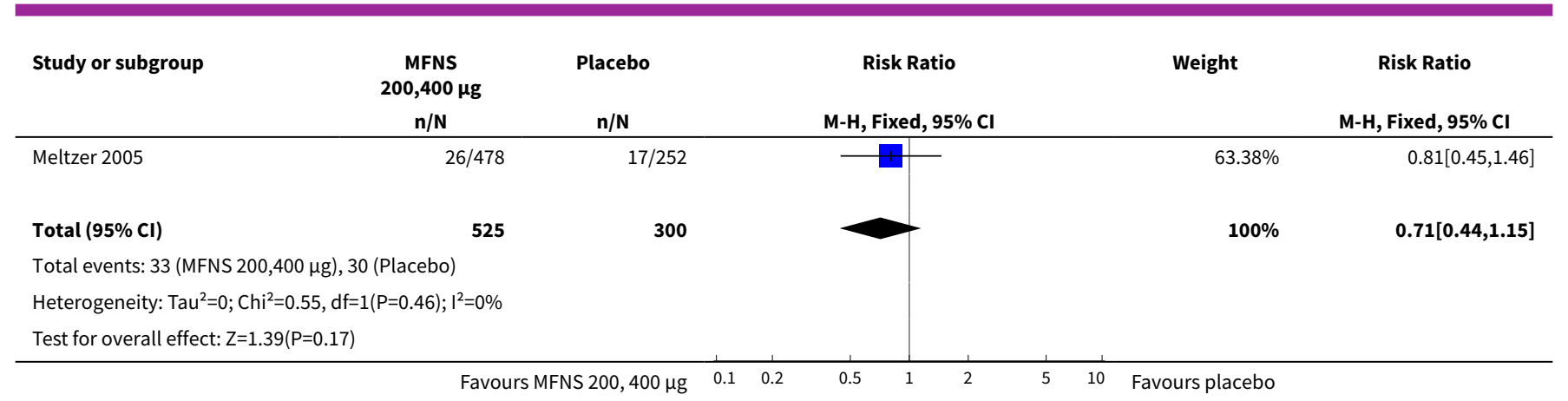

\section{ADDITIONAL TABLES}

Table 1. Adverse events

\begin{tabular}{|c|c|c|}
\hline Study & Intervention & Side effects \\
\hline Dolor 2001 & $\begin{array}{l}\text { Fluticasone propionate } 2 \text { puffs } \\
\text { - total dose } 200 \mu \text { g or placebo } \\
\text { nasal spray once daily in addi- } \\
\text { tion to } 250 \text { mg cefuroxime axetil } \\
\text { orally twice daily and } 2 \text { puffs of } \\
\text { xylometazoline hydrochloride } \\
\text { twice daily }\end{array}$ & $\begin{array}{l}\text { Headache, bloody nose, vagi- } \\
\text { nal itching, yeast infection, } \\
\text { nausea, stomach irritation, di- } \\
\text { arrhoea, increased congestion, } \\
\text { hay fever, light-headed, sore } \\
\text { throat, thirsty, itching, rash, } \\
\text { cough, fatigue, metallic taste, } \\
\text { felt dried out, nasal tissue felt } \\
\text { inflamed }\end{array}$ \\
\hline
\end{tabular}

\section{Comments}

No serious unexpected adverse events reported

Any adverse event - 37\% in the fluticasone group versus $20 \%$ in the placebo group ( $P$ val$\mathrm{ue}=0.7)$ no statistical significant difference

Adverse events could be attributed also to the co-treatment

Nayak 2002 Amoxicillin-clavulanate potassium $875 \mathrm{mg}$ twice daily orally and MFNS $200,400 \mu \mathrm{g}$ or placebo nasal spray twice daily
Epistaxis was the most frequently reported adverse event

Nasal burning, irritation and headache occurred in less than $2 \%$ of any treatment group
Treatment well-tolerated, adverse events similar for all 3 arms of mild/moderate intensity: $12 \%, 15 \%, 15 \%$ in the MFNS 400, $800 \mu \mathrm{g}$ and placebo arms

50 patients discontinued treatment because of adverse events, most commonly diarrhoea and nausea due to the antibiotic and were equally distributed among groups. Epistaxis, nasal burning, irritation or infection were not a cause for discontinuation of treatment

No specific adverse events related to the INCS use were reported
Barlan 1997 Budesonide $50 \mu \mathrm{g}$ or placebo nasal spray to each nostril bid in addition to amoxicillin clavulanate potassium $40 \mathrm{mg} / \mathrm{kg} /$ day tid
Rash after 1 week attributed to the antibiotic in 1 subject that was switched to cefaclor
Most adverse events were mild or moderate with a similar incidence among treatment groups: $36.2 \%$, $35.4 \%, 33.5 \%$ and $38.1 \%$ with MFNS $200 \mu \mathrm{g}$, $400 \mu \mathrm{g}$, amoxicillin and placebo $1 \%, 3 \%, 2 \%$ and $2 \%$ of participants discontinued treatment because of adverse events in the $200 \mu \mathrm{g}, 400 \mu \mathrm{g}$ INCS, antibiotic and placebo arms 
bid: twice daily

INCS: intranasal corticosteroid

MFNS: mometasone furoate

tid: three times daily

\section{AP PEN DICES}

\section{Appendix 1. Previous search strategy}

For this update we searched the Cochrane Central Register of Controlled Trials (CENTRAL) 2011, Issue 2, part of The Cochrane Library, www.thecochranelibrary.com (accessed 25 May 2011), which contains the Cochrane Acute Respiratory Infections Group's Specialised Register; MEDLINE (September 2008 to May week 2, 2011) and Embase.com (October 2008 to May 2011). See Appendix 1 for details of previous searches.

Previously we searched the Cochrane Central Register of Controlled Trials (The Cochrane Library 2008, Issue 4) which contains the Cochrane Acute Respiratory Infections Group's Specialised Register, MEDLINE (January 1966 to October 2008), EMBASE (1990 to October 2008) and bibliographies of included studies.

MEDLINE was searched using the following keywords and MeSH terms in conjunction with the highly sensitive search strategy designed by The Cochrane Collaboration for identifying randomised controlled trials (Lefebvre 2008). The same strategy was used to search CENTRAL and adapted to search EMBASE.

\section{MEDLINE (OVID)}

1 exp SINUSITIS/

2 sinusit*.tw.

3 rhinosinusit*. tw.

4 or/1-3

5 exp STEROIDS/

6 steroid*.tw.

7 exp Adrenal Cortex Hormones/

8 adrenal cortex hormone*.tw.

9 exp Anti-Inflammatory Agents/

10 anti-inflammat ${ }^{\star}$.tw.

11 corticosteroid*. tw.

12 or/5-11

13 exp Administration, Intranasal/

14 exp Administration, Topical/

15 (nasal $^{*}$ or intranasal ${ }^{\star}$ or topical ${ }^{\star}$ ).tw.

16 or/13-15

1712 and 16

184 and 17

\section{Appendix 2. Embase.com search strategy}

\#24 \#16 AND \#23

\#23 \#22 NOT \#21

\#22 \#17 OR \#18

\#21 \#19 NOT \#20

\#20 'human'/de

\#19 'animal'/de OR 'nonhuman'/de OR 'animal experiment'/de

\#18 random ${ }^{\star}:$ ab,ti OR placebo*:ab,ti OR crossover*:ab,ti OR 'cross over':ab,ti OR allocat*:ab,ti OR trial:ti OR ((doubl OR singl $\left.{ }^{\star}\right)$ NEAR/1 blind*):ab,ti

\#17 'randomized controlled trial'/exp OR 'single blind procedure'/exp OR 'double blind procedure'/exp OR 'crossover procedure'/exp \#16 \#4 AND \#11 AND \#15

\#15 \#12 OR \#13 OR \#14

\#14 nasal*:ab,ti OR intranasal*:ab,ti OR topical* $^{*}$ ab,ti

\#13 'topical drug administration'/de

\#12 'intranasal drug administration'/de

\#11 \#5 OR \#6 OR \#7 OR \#8 OR \#9 OR \#10

\#10 'adrenal cortex hormone':ab,ti OR 'adrenal cortex hormones':ab,ti

\#9 'anti-inflammatory':ab,ti OR 'anti-inflammatories':ab,ti OR antiinflammat*:ab,ti OR 'anti inflammatory':ab,ti OR 'anti inflammatories':ab,ti 
\#8 'antiinflammatory agent'/exp

\#7 'corticosteroid'/exp

\#6 steroid*:ab,ti

\#5 'steroid'/exp

\#4 \#1 OR \#2 OR \#3

\#3 rhinosinusit* $:$ ab,ti OR nasosinusit* ${ }^{*}$ ab,ti

\#2 sinusit*:ab,ti

\#1 'sinusitis'/exp

WHAT'S NEW

\begin{tabular}{lll}
\hline Date & Event & Description \\
\hline 19 August 2019 & Amended & Lead author's contact details have been updated. \\
\hline
\end{tabular}

\section{HIST ORY}

Protocol first published: Issue 1, 2005

Review first published: Issue 2, 2007

\begin{tabular}{|c|c|c|}
\hline Date & Event & Description \\
\hline 22 May 2013 & $\begin{array}{l}\text { New citation required but conclusions } \\
\text { have not changed }\end{array}$ & Our conclusions remain unchanged. \\
\hline 22 May 2013 & New search has been performed & Searches updated. No new trials were identified in this update. \\
\hline 25 May 2011 & $\begin{array}{l}\text { New citation required but conclusions } \\
\text { have not changed }\end{array}$ & $\begin{array}{l}\text { Searches updated. No new studies found for inclusion or exclu- } \\
\text { sion. The conclusions remain unchanged. }\end{array}$ \\
\hline 3 June 2010 & Amended & Contact details updated. \\
\hline 28 October 2008 & $\begin{array}{l}\text { New citation required but conclusions } \\
\text { have not changed }\end{array}$ & $\begin{array}{l}\text { Two trials identified in the updated search and three trials for } \\
\text { which data are not available were added to the excluded studies } \\
\text { list (Bachert 2007; Jurkiewicz 2004; Meltzer 2000; Tutkun 1996; } \\
\text { Williamson 2007). }\end{array}$ \\
\hline 28 October 2008 & New search has been performed & Searches conducted. \\
\hline
\end{tabular}

\section{CONTRIBUTIONS OF AUTHORS}

Dr Anca Zalmanovici wrote the review, searched the literature, selected the studies to be included, assessed their quality, entered the data into RevMan 2012, wrote the methods, results and discussion sections and updated the review.

Dr John Yaphe searched the literature, was an independent assessor in selecting trials to be included, assessed the quality of the trials, wrote the discussion section and edited the review.

\section{DECLARATIONS OF INTEREST}

None known.

\section{NOTES}

We thank Professor Leonard Leibovici from the Rabin Medical Center and Professor Michael A Weingarten, of the Department of Family Medicine, Tel-Aviv University, for their useful suggestions and final revision of this review. 


\section{N D EX TERMS}

\section{Medical Subject Headings (MeSH)}

Acute Disease; Administration, Intranasal; Adrenal Cortex Hormones [ ${ }^{*}$ administration \& dosage]; Randomized Controlled Trials as Topic; Sinusitis [ ${ }^{\star}$ drug therapy]

\section{MeSH check words}

Adult; Child; Humans 